\title{
Laissez-Faire Environmental Policy Implementation and Fako Urban Blight, Cameroon
}

\author{
Sunday Shende Kometa \\ Associate Professor of Geography, Head of Geography Department \\ University of Bamenda, Cameroon \\ E-mail: shendek@hotmail.com
}

Cornelius Mbifung Lambi

Professor Emeritus, Department of Geography, University of Buea, Cameroon

E-mail: lambimc@yahoo.com

Tata Emmanuel Sunjo

Ph.D. Fellow, Department of Geography, University of Buea, Cameroon

E-mail: tataemmanuel@ymail.com

Received: October 19, 2018 Accepted: November 3, 2018 Published: January 25, 2019

doi:10.5296/emsd.v8i1.14264 URL: https://doi.org/10.5296/emsd.v8i1.14264

\begin{abstract}
While legislation exist to regulate urban development, there is unfortunately a wide spread disrespect of the urban environmental policies which could stem the host of challenges that could impair human wellbeing and livelihoods of the urban dwellers. This paper examines the non implementation of the urban environmental laws using the Anthropic Interference Model (AIM) which posit that human interference with the drainage channel within city environments accounts for increased flood frequencies and flood magnitudes. The study for Buea, a highland town and Limbe, a low coastal city shows that there is an incredible degree of human interference with the existing drainage systems which is the results of the urban flood hazards, the unhealthy wet environments and the urban aesthetic blight. In view of these prevailing conditions, the paper recommends a strong sensitization of the urban population on the need to respect the legislation enforced as a move toward the building of sustainable cities. Apart from the raising of public awareness, there should be a strict
\end{abstract}


application of the law in which the demolition of structures that contravene the law should serve as a deterrent to future non compliance. This would be an effective measure for parting with the long standing urban environmental Laissez-faire that has plagued our Cameroonian towns.

Keywords: Laissez-Faire, Environnent, Policy implementation, Fako Urban Blight, Cameroon

\section{Introduction}

Urban centres have grown up in varied physical environments. Given that such varied environments have their unique environmental problems, town planning and the implementation of urban environmental policies play a key role in stemming a number of these challenges in a bid to enhance the living conditions of urban dwellers. The objective of this paper is to examine how the non-implementation of urban environmental laws in Fako Division has remained a panacea for flood hazards, and poor and haphazard development. In effect, because of failed implementation of the urban environmental laws and the consequent emergence of urban aesthetic blight in Limbe and Buea, these emerging cities in a volcanic and humid tropical environment thus play host to a number of environmental problems.

The paper examines the bastardisation of environmental laws with respect to urban drainage basins using the Anthropic Interference Model (AIM) which was proposed by Kometa (2005) when he examined the problem of floods in the Limbe Municipality. The basic tenets of this model emphasises the fact that water flow channels in urban environments as elsewhere should be free from any degree of human interference as the human modifications of water flow channels can have disastrous effects in terms of flooding and flood magnitudes. Furthermore, the theory presupposes that a sustainable management of the urban drainage system would rely heavily on channel modification which relates to the widening and deepening of water flow channels as experience from geographic literature teaches us that increasing urbanisation comes along with increased flood magnitudes. In recognition of flood related hazards, it is only germane that the constant bastardisation of laws within our cities should be checked if we too, dream of sustainable cities or eco-cities. Limbe and Buea are fast emerging cities in Fako Division where the quest for more land for housing has come along with a systematic neglect of the urban environmental laws which relate to city drainage management systems.

Illegal waste dumps and the clogging of river channels in cities lead to the constriction of the water passage ways. River clogging of this nature by plastics and other non-biodegradable materials is a prelude to flooding. In the circumstance, it seems as if man in this municipal area simply mocks at nature. Such plastic clogging behaves in much the same way as the woody debris as it is the case within the temperate areas of Japan and China. So, this is a clear indication that urban floods are a direct response to human bastardisation of the drainage channels. This degree of urban pollution and unhygienic scenario is predicated first and foremost on the mentality of urban dwellers who do not understand the need for proper urban waste disposal. This suggests that in the area of sensitisation, the municipal stakeholders and the municipal authorities in particular still have a herculean task to 
accomplish.

\section{The Problem}

Urban environmental laws regulate the growth and development of cultural or man-made structures within the city or built-up environments in relation to the drainage network, river channels, runoff channels, dry valleys and wetlands. Wetland environments have been reclaimed for building purposes. Some city water channels have been reduced through human encroachment. Others have been partially blocked. Yet, the increasingly paved surfaces of urban environments tend to increase flood frequencies and magnitudes. Present day urban growth in many Cameroonian cities is taking place in the midst of the laissez-faire phenomenon in terms of the urban environmental laws and limited planning signposts. The dysfunctioning of the urban laws and policies suggest that urban aesthetic blight is thus an inevitable welcome scenario while the concept of eco-cities remains a dream in the face of the present trend of urban development in Fako Division. This paper therefore examines the modification of river channels, namely, the widening and the deepening of stream channels to enhance stream flow during periods of over-floods and the negative impacts of the proximal location of housing infrastructures to the river channels without respect of the statutory buffer distances as required by the urban environmental law of Cameroon.

\section{Research Methods}

This study uses the standard social science methodology of fieldwork for data collection, data analysis and the discussion of results. Primary data were obtained through field observations of river channel ways and other swampy urban environments in an attempt to evaluate the degree of human modifications through infrastructural developments as well as the clogging of river channels by plastics and other waste materials. Field measurements were done in order to determine the degree of human encroachment especially the construction of homes into the wet perimeter of the river channels. These methods were accompanied by interviews of some urban dwellers on their experiences regarding river channel modifications and the possible way forward. Furthermore, the Cameroon urban environmental policies provided the information against which field realities were verified. These data were analysed qualitatively with results presented in the form of figures and tables.

\section{Discussion of Results}

\subsection{Nature of Urban Valleys and Streams}

Within the Fako volcanic terrain, many valleys or interfluves which are natural runways for water during the wet season stand out as dry valleys. The purchase and utilisation of these dry valleys is a partial springboard for the occurrence of floods within some portions of our urban environments. Some of these valleys have undergone profound positive modification by man and these can be seen through valley enlargement and valley deepening which are strategies to enhance the free-flow of excess flood waters through the increased water holding capacity of the channel. This increased water holding capacity reduces the occurrence of floods. This strategy has been amplified with an excellent degree of success in metropolitan Yaounde. The broadened and deepened valleys have nullified the adverse flood impacts that brought more 


\section{Macrothink}

hardship to the urban poor who sometimes flock into urban wetlands or their surrounding neighbourhoods.

\subsection{Negative Modifications of Urban Drainage Systems}

Negative valley modifications include an encroachment of human infrastructures into valleys and flow channels, the blockage or river channels through house construction and the clogging of other flow channels. The increasing poor urban practices have come at a wrong time because there is increasing urbanisation which increases flood magnitudes. This incidence of increased flood magnitudes calls for much more elaborate drainage systems in order to cope with the increased volumes of water from urban floods. On the contrary, there is the absence of sufficient drainage system water holding capacity. This reduction inevitably paves the way for increased floods over time.

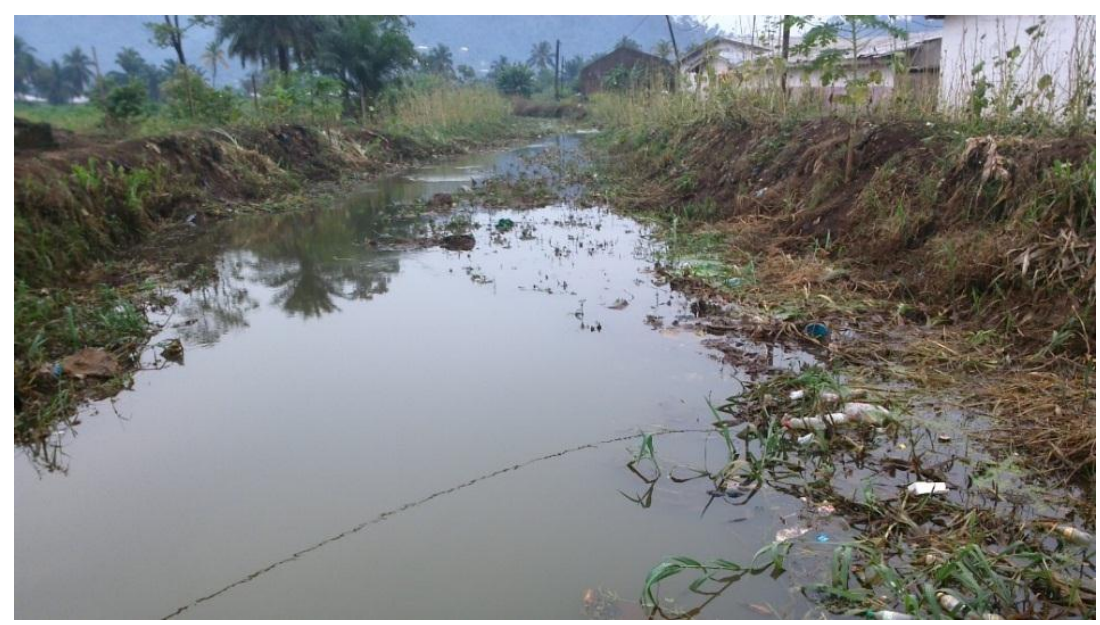

Figure 1. Flow channel of the Jengelle Stream through the Limbe New Market. The narrow and shallow channel along Manga William Street accounts for the repeated and rapid over-floods during the rainy season

Moreover, we are in a period of increasing global warming which implies that there is an increased probability of much heavier rainfall in the future. While these projected increases call for a future elaboration of the urban drainage networks and urban drains, there is a gradual ongoing reduction in the water holding capacity of city channel ways through the growing bastardisation of urban environmental laws and policy through their non-implementation.

The problem of poor urban management arising from the government laissez-faire attitude towards the implementation of urban environmental policy is a long standing disease that has plagued the Cameroonian urban centres since independence. Under the former British Colonial Rule, urban sanitation had its pride of place through the vigorous sanitation inspection officers who ensured the strict implementation of the law with regards to urban sanitation. Under this sanitary regime, there were strict laws against littering and the haphazard dumping of garbage either in the urban stream, urban valleys, or other open space. These are good urban practices which the urban dwellers were forced to cope with since there 
were uncompromising fines and consequences for the non-implementation of urban laws or policies. However, as with all other human systems, a laissez-faire attitude towards the implementation of the laws or policies everywhere opens the corridor for anarchy and disrespect of the law. This is the cause of our aesthetic urban blight today.

\subsection{Urban Environmental Policy and Development}

Most dwellers in Cameroonian cities have grossly defied the urban environmental policy which stipulates that there should be no man-made structures on land across or besides the river. Within the two municipalities in question, the proximal locations of a host of infrastructures which are less than 5 metres to the stream are glaring examples of the bastardisation of the urban environmental laws. Most structures extend to the edge of the river valleys. Some encroach into the river valley (Figure 2)

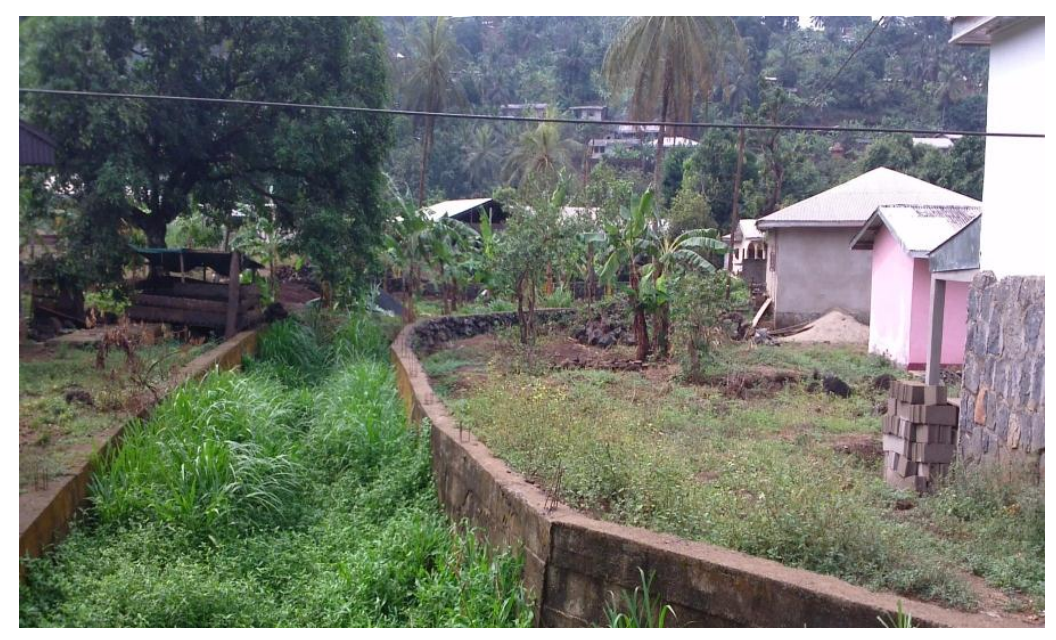

Figure 2. Human encroachment into the river valley in the Mabeta New Layout Brook

(Limbe) leading to valley constriction through the illegal reclamation of flow channel.

More than two thirds of the valley width has thus been encroached upon

Meanwhile, other property owners close to the streams and valleys such as the Ndibe actually colonise part of the water run-way in the name of reclamation. In most cases, this illegal reclamation of the water runway drastically reduces the free passage of water. When natural valleys have been constricted in size, their water holding capacities are also drastically reduced. But the bad news is that man can do nothing to reduce the annual rainfall that excavated those valleys which are now under human interference. At the same time, increasing urbanisation increases flood magnitudes. These are all consequences which human encroachments have not addressed. The most ridiculous of "urban land grabbing" is where man builds astride the water or channel runways. In the natural scheme of things, flow discharge ways within this volcano-karst district cannot be stopped from functioning with occasional rain storms which are characteristic of these humid tropical towns. Perhaps, this kind of channel blockage is the most senseless fight against nature. After all, nature takes its time and it is in no hurry to show that it is in command and that no one can successfully fight it. The Bomaka-Wonya Mavio settlements are excellent examples of valley constriction 


\section{Macrothink}

which is not in the best interest of the municipalities as this process leads to increased downstream flooding (Figure 3). While the data for valley or channel encroachment are enormous, it is perhaps necessary to highlight the existing situation in the two municipalities.

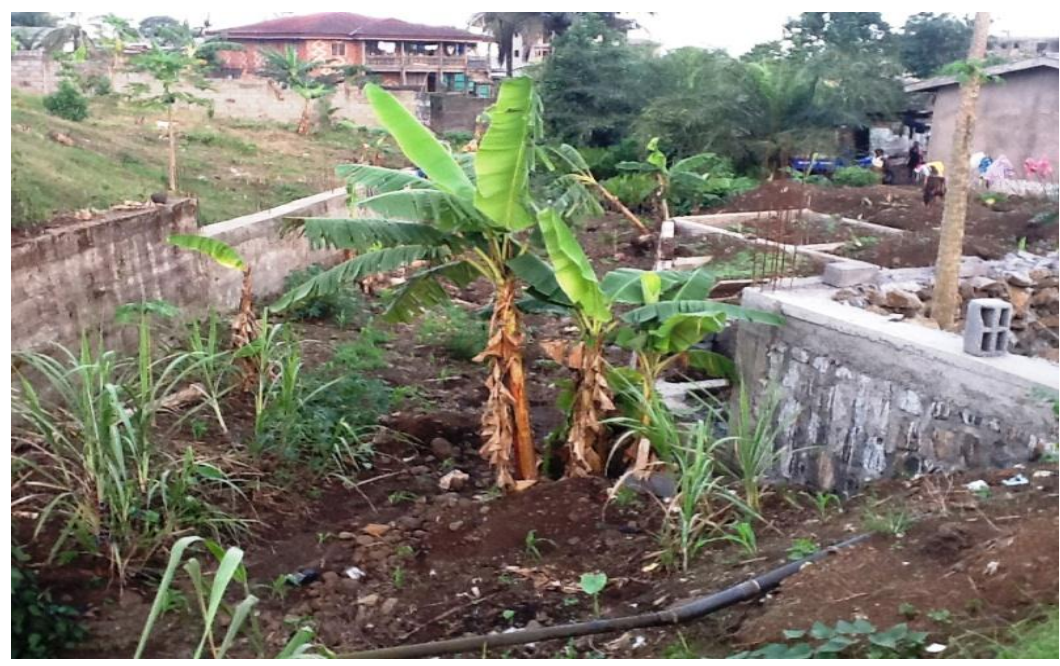

Figure 3. Valley Encroachment through Reclamation induces flooding of Chief Street Road Downstream during the Rainy Season

Around the Buea Chariot Hotel, there is an amphitheatre-like valley network. All flood waters from this valley network are channelled downstream across the highway through a small culvert of less than two metres in diameter. Within the downstream part itself, there are some building constructions inside the $8-10 \mathrm{~m}$ deep valley which cut across $82 \%$ of the channel leaving only a paltry $18 \%$ of it for the flow of water and runoff (Table 1). This is indeed an aberration in urban planning particularly when individuals mistakenly take upon themselves to block the drainage channels because such valleys or interfluves fall within the land they purchased. This false ownership standpoint undermines the fundamental legal provision which advocates the right of access and availability of the same water resource to the downstream users. But the dry valleys which carry ephemeral streams during the wet seasons which actually pass for common property resources (CPRs) can never be personalised as individual property. These urban anomalies should be halted before the housing density becomes much more elaborate and complex to induce a run-away management state. Near Blessed Hostel, along Bomaka Chief Street, a building has been constructed astride part of the $25 \mathrm{~m}$ broad dry valley interfluves (Figure 4), thus blocking the flow of surface runoff. Similar constructions have been made along some of the interfluves at Bunduma among others with very limited access for runoff. These are all very classical examples which relate to the total disregard and rape of the environmental and planning policies at the dawn of the $21^{\text {st }}$ Century. 


\section{Ml Macrothink}

Environmental Management and Sustainable Development

ISSN 2164-7682 2019, Vol. 8, No. 1

Table 1. Some Examples of Valley Widths in the Limbe and Buea Municipalities

\begin{tabular}{|l|c|c|c|l|}
\hline Name \& Location & $\begin{array}{c}\text { Valley } \\
\text { Widths }\end{array}$ & $\begin{array}{l}\text { Present } \\
\text { Widths }\end{array}$ & $\begin{array}{c}\text { Percentage } \\
\text { Encroachment }\end{array}$ & \multicolumn{1}{|c|}{ Environmental Consequences } \\
\hline $\begin{array}{l}\text { Brook in the } \\
\text { Mabeta New Layout } \\
\text { (Limbe) }\end{array}$ & $17.5 \mathrm{~m}$ & $6 \mathrm{~m}$ & $65.7 \%$ & $\begin{array}{l}\text { Increased downstream flooding; Temporary } \\
\text { water stagnation and over floods around the } \\
\text { constructed valley zone }\end{array}$ \\
\hline $\begin{array}{l}\text { Ndibe River (New } \\
\text { Town, Limbe) }\end{array}$ & $11 \mathrm{~m}$ & $6 \mathrm{~m}$ & $46 \%$ & $\begin{array}{l}\text { Built up structures stretch to river banks; } \\
\text { Increased flood risk during rain storms }\end{array}$ \\
\hline $\begin{array}{l}\text { Jengele (Church } \\
\text { Street Limbe) }\end{array}$ & $7.5 \mathrm{~m}$ & $4 \mathrm{~m}$ & $46.6 \%$ & $\begin{array}{l}\text { Built up structures stretch to river banks; } \\
\text { Increased flood risk during rain storms }\end{array}$ \\
\hline $\begin{array}{l}\text { Mile 1 New Layout } \\
\text { (Limbe) }\end{array}$ & $16 \mathrm{~m}$ & $8 \mathrm{~m}$ & $50 \%$ & $\begin{array}{l}\text { Increased flooding and prolonged persistence of } \\
\text { wetland conditions }\end{array}$ \\
\hline $\begin{array}{l}\text { Bomaka Area } \\
\text { (Buea) }\end{array}$ & $16 \mathrm{~m}$ & $8 \mathrm{~m}$ & $50 \%$ & $\begin{array}{l}\text { Temporary surface water stagnation; Flooding of } \\
\text { the Chief Street road downstream during the } \\
\text { rainy season; Liability to future flood disasters }\end{array}$ \\
\hline $\begin{array}{l}\text { Wonya Mavio } \\
\text { (Chariot } \\
\text { Hotel-Buea) }\end{array}$ & $25 \mathrm{~m}$ & $4 \mathrm{~m}$ & $82 \%$ & $\begin{array}{l}\text { Aesthetic blight; Flood risks and increased } \\
\text { downstream flood magnitudes }\end{array}$ \\
\hline $\begin{array}{l}\text { Chief Street } \\
\text { Bomaka }\end{array}$ & $30 \mathrm{~m}$ & $12 \mathrm{~m}$ & $60 \%$ & $\begin{array}{l}\text { Building astride valleys with restricted space for } \\
\text { rainy season flood waters and runoff }\end{array}$ \\
\hline
\end{tabular}

The total blockage of some flow channels creates temporary swampy conditions which dry out with difficulty. When water is forced to stagnate, these temporary swampy conditions hamper the easy movement of people within the neighbourhood. These wetlands are also not healthy environments as they play host to parasites of some diseases like malaria. Parts of the wet perimeters of some valleys actually consist of walls of houses. Here, man provokes nature in the mistaken belief that he is in control and can modify parts of the earth's surface to suit his convenience. In no circumstance whatsoever should man undertake these negative environmental modifications because it amounts to fighting nature and undermining the urban environmental legislation that have put in place to check the unsustainable haphazard development within city environments. The building of structures across channel ways goes contrary to the environmental ordinance which prescribes that permanent flood channel ways should be established through the respect of the rights-of-way. Why simple environmental policies cannot be respected remains a great cause for concern in the face of the modern drive for proper planning to give a facial uplift at a time when our settlement agglomerations are growing into ugly and monstrous monumental urbanscapes. 


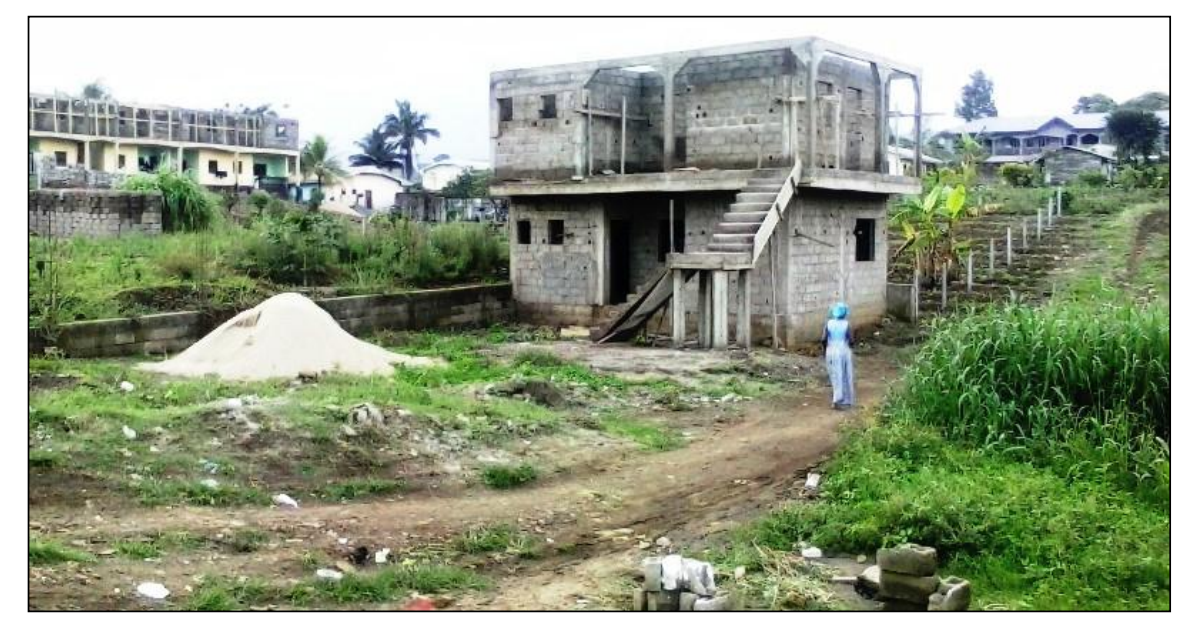

Figure 4. Buildings Construction astride the dry valley Interfluves near Blessed Hostel along Chief Street, Bomaka. The House is protected by a short concrete wall near the base to prevent an inundation of the lower portion of the house

\subsection{The Buffer/Wet Perimeter Problem}

There is the need for the creation of buffer zones on both sides of river channels. These actually represent the maximum wet perimeters or the maximum levels to which flood waters can rise in the case of unprecedented floods. Table 2 shows the approximate values which are stipulated by Cameroon's environmental policy.

Table 2. Free buffers between streams and human infrastructures

\begin{tabular}{|l|l|}
\hline Widths of Streams/Water Channels & \multicolumn{1}{c|}{ Standard Widths of Buffer Zones } \\
\hline Streams less than $5 \mathrm{~m}$ wide & $15 \mathrm{~m}$ on both sides of the river \\
\hline $\begin{array}{l}\text { Streams larger or wider than } 5 \mathrm{~m} \\
\text { (Rivers between } 5-10 \mathrm{~m} \text { or more) }\end{array}$ & $\begin{array}{l}30 \mathrm{~m} \text { buffer zone on both sides of the river. This distance factors } \\
\text { in the wet perimeter of the river valley. }\end{array}$ \\
\hline
\end{tabular}

These are Approximate Dimensions of Valley Wet Perimeters

Wide spread experience in Cameroon as a whole shows that the buffer zones which are required to be left on both sides for urban streams of the different dimensions are never respected. These required distances actually pass for the wet perimeters of streams during unprecedented over-floods. Periodically, greater flood magnitudes are never likely to affect man-made infrastructures which respect the prescribed distances. This is government's device of fighting the disastrous effects of urban floods whenever they are to occur. There is practically no where in these two municipalities where these dimensions of buffers are respected. However, where dredging involving valley widening and valley deepening is undertaken by the municipalities, the non-respect of buffer widths could have no adverse consequences. The building of some protective embankments could also nullify the disastrous effects of bank overflows or outburst in the case of proximal locations of houses to stream channels. It is therefore necessary that the issue of urban buffers and wet perimeters should be taken seriously if we dream of building up sustainable cities for our highly globalised world. 


\section{$\triangle$ Macrothink}

\subsection{Urban Culverts}

Small streams, brooks or rivulets in cities are most often provided with only small culverts to serve as passage ways for flood waters and bridges linking both sides of urban rivulets. Given their usual small dimensions, clogging by transported debris or other urban wastes like plastics cause floods especially when accumulated debris play a similar role like that of the woody debris. Many of our urban streams cannot flow efficiently because they are carpeted and clogged by plastic bottles, broken plastics and other non-biodegradable materials. While the issue of illegal dumping in urban streams needs to be seriously addressed, the municipalities should upgrade and expand the urban culverts into urban bridges which could allow a higher and freer degree of river flow as a result of the increased water holding capacity of the valley.

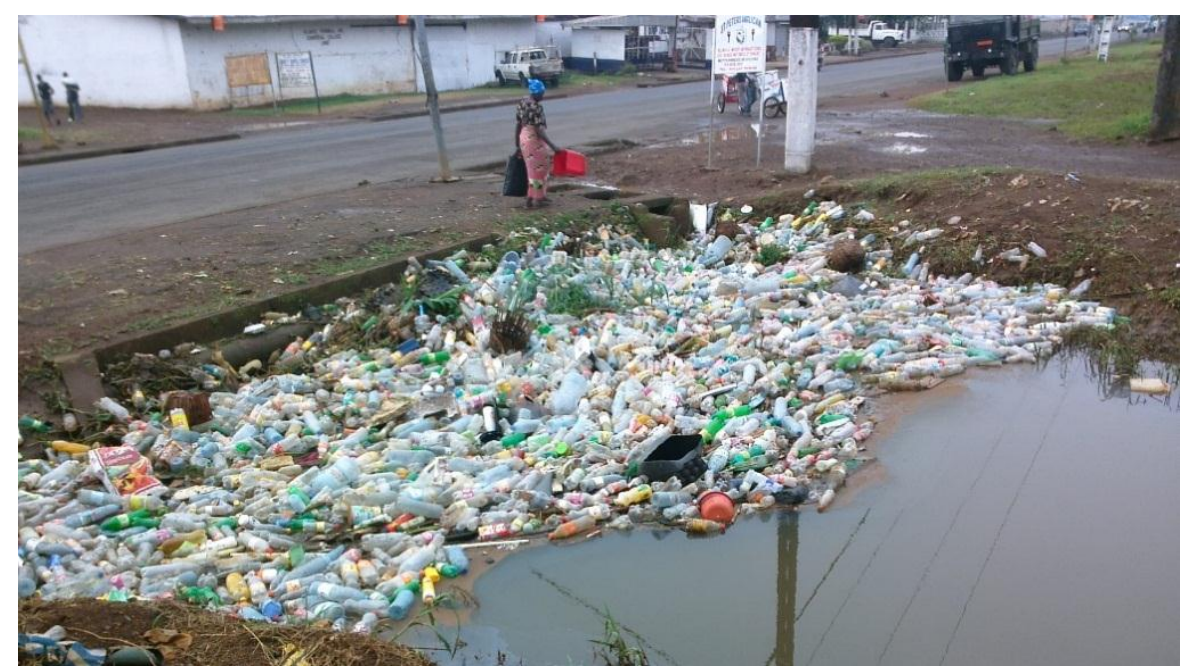

Figure 5. Urban culvert along Manga William Street, Limbe. The constricted nature of the culvert dimension stands at the origin of river blockage. Only culvert enlargement can ensure the free passage of water downstream

Furthermore, to solve the problem of river clogging by debris and wastes from the illegal stream dumpsites, a waste trap mechanism should be put in place farther upstream to hold back any assorted debris from clogging the culverts. With growing city expansion, growing population and a consequent higher degree of waste generation, municipal authorities do not have enough options opened to them than the constant channel upgrading and the building of much broader and elevated bridges across the several urban streams that run through the municipality.

\subsection{Local Council Controls}

The government of Cameroon has empowered the local or municipal councils to protect and control the urban drainage systems and their surrounding neighbourhoods. So the control of haphazard developments which tend to impede the free flow of water becomes the duty of the urban supervisory authorities. The lapses in the enforcement of these urban policies perhaps lie in the domain of bribery and corrupt practices whereby the urban authorities give a blind 
eye to such sprouting structures which contribute to urban blight at a time when mankind should be focusing on the growth of sustainable cities as it is the case in many parts of the world today.

\subsection{Urban Wetland Conservation}

Cameroon's urban environmental policy also forbids the dislocation of urban wetlands through human interference for development purposes. Planning regulations state that lands which are suitable for intensive development because of flooding, unsuitable soil conditions, or where the provision of essential public services and other facilities is difficult, should be maintained in suitable open space use. Furthermore, these planning regulations also stipulate that intensive urban development should be directed so as to avoid flood plains.

The public development of flood hazard areas for recreation and aesthetics has long been recognised as a suitable strategy of flood plain management and conservation. Green belts or underdeveloped areas along urban streams can also provide the much needed or valuable breaks in the monotony of urban sprawl. Another unsuitable use of wetlands is the construction of municipal packing lots. But in the developing countries however where corruption is rife and autocratic systems fuelled by the political and administrative elite prevail, everything goes. In so doing, even well designed policies and environmental innovations which are designed to overturn the impact of environmental hazards are down played or swept under the carpet. Here, the respect of the law remains primordial for planned urban growth everywhere. In spite of the existing policy in this respect and the harsh realities of wetlands environments, man has, however, defied nature and the law. It has thus become a commonplace practice for reclamation schemes to be carried out in a host of the urban swamps to gain additional land for the building of homes. Other forms of human interference include small scale agricultural purposes like market gardening. The spirit behind the urban wetlands is simple. These are huge reservoirs which should hold excess water from heavy tropical rain storms and the general runoff during floods. The eradication or obliteration of urban swampy areas means that there is no longer any room for accommodating the incoming urban flood waters which can only flow away or subside with time, days or weeks after the flood occurrences. Furthermore, the conservation of wetland ecosystem and ecosystem functions is a tacit duty as such natural landscapes muffles the harshness of the urban monotony of houses and other built-up structures. Moreover, their aesthetic and recreational values cannot be underestimated in a world of increasing urbanisation.

When such reservoirs are depleted through reclamation, the overall balance sheet is increased flooding in the urban downstream areas. It is for these reasons therefore that state policy stipulates a human non-interference with the urban wetlands. In the Mabanda (Douala) wetlands for example, government has gone on the rampage to break down the homes that have mushroomed within the forbidden or no go wetlands since man has opted to bastardise the urban environmental policy of no human interference.

The Limbe Clerks Quarters, the Mile 1 New Layout and Motowo are some classical type areas of wetland environments. But these have been invaded by man for settlement with varying degrees of inadequate adaptations to floods. Here, flood waters are common visitors 
which hang around for long periods every year as the water table is close to the surface. The Down Beach area is a different story altogether where man, is either exposed to the inland floods surges and sea incursions signally a double tragedy. Around Bomaka and the Bolifamba Mile 16 settlements, the wetlands as well have known no rest from man's interference with nature as timid housing structures are gradually gaining ground. The haphazard growth of houses and other urban structures in poor, unhealthy and environmentally forbidden or unacceptable environments is the bedrock of the existing urban aesthetic blight in many of the Cameroonian cities. The non-implementation of the urban environmental laws for the coastal and montane cities of Limbe and Buea respectively, is demonstrated by the urban growth without respect to the drainage network and the consequent flood occurrences during heavy tropical rainstorms.

So given the prevailing circumstances, man in the present highly technological age in which we live, still unfortunately remains at the mercy of natural disasters following our gross disrespect of nature through human interference which makes us vulnerable to storm floodwaters. Thus, the wetlands as distinct ecosystems have their pride of place with respect to the functions they provide.

\section{Conclusion}

The laws against the haphazard dumping of wastes along drainage ways exist. But it would seem that the city stakeholders require a great deal of sensitisation to inform the city dwellers of the negative repercussions on health, social wellbeing and aesthetic values of the haphazard and illegal dumping within city environments. Urban aesthetics blight is a predominant phenomenon in our cities of most low income developing economies. The underlying reason for this poor status quo has been the non-respect or the non-implementation of the existing urban environmental laws which relate to good urban drainage practices. The issue of urban beautification can not be left to chance. This explains why the neglect of policy enforcement is contributing to the increasing urban blight against the backdrop of much higher expectations of eco-cities at the dawn of the $21^{\text {st }}$ Century.

This study confirms Kometa's (2005) Anthropic Interference Model (AIM) that the sum total of human negative environmental interactions with the urban drainage network accounts for the increasing flood magnitudes. For some of the modifications which served as topographic traps, this would imply that not all the rivulets, streams, and springs could flow undisturbed by man-made structures. As such, flood waters are forced to stagnate during the heavy rainy season storm downpours. Some semi-permanent to transient water bodies are thus forced to stagnate as they do not have constant evacuation routes leading to peak flood heights which may vary from one to nearly two metres in different parts of the Limbe Municipality. The cases of Limbe Clerks Quarters and the Motowo/Jengele and the Mile 1 New Layout areas have been particularly remarkable in this respect.

\section{References}

Bassi, N., Kurmar, M. D., Sharma, A., \& Pardha-Saradhi, P. (2014). Status of wetlands in India: A review of extent, ecosystem benefits, threats and management strategies. Journal of 
Hydrology: Regional Studies, 2, 1-19.

Boyer, T., \& Polasky, S. (2004).Valuing Urban Wetlands: A Review of non material valuation Studies Wetlands, 24, 744-755.

Fogwe, Z. N. (2007). The Transformation of an Urban Internal Watershed in to a Wasteshed due to Industrial Zone Location Policy in Cameroon: The case of the Bassa Industrial Zone, Douala. Annals of the Faculty of Arts, Letters and Social Sciences, 1(6), 323-338.

IPCC, (2007b). Climate Change 2007: Mitigation. Contribution of Working Group III to the Fourth Assessment Report of the Intergovernmental Panel on Climate Change. B. Metz, O. Davidson, P. Bosch, R. Dave and L. Meyer, Eds., Cambridge University Press, Cambridge, UK.

Kometa, S. S. (2005). The Impacts of Natural and Man-induced Hazards in Fako Division. SouthWest Region, Unpublished Ph.D. Thesis, Department of Geography, University of Buea.

Lambi, C. M., Kometa, S. S., \& Fombe, L. F. (2002). Environmental Hazards and Landuse Planning for Sustainable Development: The Limbe Unstable Coastal Region, Cameroon, in International Geo-technical Conference, Instability-Planning and Management, Ventnor, Isles of White, Thomas Telford, London, United Kingdom, pp. 151-159

Maltby, E. (1986). Waterlogged Wealth: Why Waste the World's Wet Places. Earthscan, London, UK.

McKinney, M. L. (2002). Urbanization, Biodiversity, and Conservation. Bioscience, 52, 883-890. https://doi.org/10.1641/0006-3568(2002)052[0883:UBAC]2.0.CO;2

McInnes, R. (2010). Urban development, Biodiversity and Wetland Management, Expert Workshop Report, Bioscan (UK) Ltd Oxford, UK

Ramsar Convention Secretariat (2013). The Ramsar Convention Manual: a guide to the Convention on Wetlands (Ramsar, Iran, 1971), 6th ed Ramsar Convention Secretariat, Gland, Switzerland (Ramsar Convention Secretariat 2013).

UNFCCC (2005). Compendium on Methods and Tools to Evaluate Impacts of, and Vulnerability and Adaptation to, Climate Change. UNFCC Secretariat, 155 pp.

UN-Habitat (2016). Urbanization and Development: Emerging Futures. World Cities Report. United Nations Human Settlements Programme.

UN-Habitat (2009). Global Report on Human Settlements 2009: Planning Sustainable Cities. Earthscan, London and Sterling, VA.

World Bank (2008). Biodiversity, Climate Change and Adaptation Nature-Based Solutions from the World bank porfolio, The International Bank for reconstruction and Development, Washington, GC 20433 USA. 


\section{Macrothink \\ Environmental Management and Sustainable Development \\ ISSN 2164-7682}

\section{Copyright Disclaimer}

Copyright for this article is retained by the author(s), with first publication rights granted to the journal.

This is an open-access article distributed under the terms and conditions of the Creative Commons Attribution license (http://creativecommons.org/licenses/by/3.0/). 